\title{
Karakter Anatomi Daun sebagai Bentuk Adaptasi Tumbuhan Penyusun Zonasi Mangrove di Banggai Kepulauan, Provinsi Sulawesi Tengah
}

\author{
Eka Fatmawati Tihurua*, Esthi Liani Agustiani dan Kusuma Rahmawati \\ Bidang Botani, Pusat Penelitian Biologi, Lembaga llmu Pengetahuan Indonesia \\ JI. Raya Jakarta-Bogor, Km. 46, Cibinong, Jawa Barat 16911 Indonesia \\ Email: etihurua@gmail.com
}

\begin{abstract}
Character of leaf anatomy as form of plant adaptation on mangrove zonation in Banggai Islands, Central Celebes
\end{abstract}

Mangrove is an essential ecosystem that are located in the transition area of fresh and sea water. Therefore, species that grow are typical species that are able to adapt to the saline environment. The aim of this research is to characterize leaf anatomical structure for every species that compose the communities found in each mangrove zonations, including their similarities and dissimilarities characteristic. Sampling of examined leaf was carried out in the mangrove areas of Peling Island and Bakalan Island by making plots in four sites of the mangrove ecosystem area. Methods for leaf anatomical preparations were carried out using the paraffin-tert-butanol and paradermal sections. Anatomical characters as an adaptation to saline habitat are found in all species of mangrove plants, including thick cuticle and epidermal cells, thick leaves and waterstorage tissue (hypodermis). In addition, there is found the presence of cork warts and sclereid as characteristic of the genus Rhizophora. Based on quantitative character observations, the mesophyll (palisade to sponge) ratio range from $0.28 \pm 0.04 \mu \mathrm{m}$ to $1.19 \pm 0.42 \mu \mathrm{m}$, leaf thickness ratio $289,41 \pm 38,21 \mu \mathrm{m}$ to $695,20 \pm 97,50 \mu \mathrm{m}$ and the highest stomata density is owned by Lumnitzera littorea.

Keywords: cork warts; hypodermis; mesophyll ratio; saline

\begin{abstract}
Abstrak
Mangrove merupakan ekosistem esensial yang berada di daerah peralihan air tawar dan air laut. Oleh karena itu, spesies-spesies yang tumbuh adalah spesies khas yang mampu beradaptasi terhadap lingkungan saline. Penelitian ini bertujuan untuk mengkarakterisasi struktur anatomi daun pada setiap spesies penyusun komunitas di masing-masing zonasi mangrove serta persamaan dan perbedaan karakter masing-masing spesies penyusunnya. Pengambilan sampel penelitian daun dilakukan di kawasan mangrove Pulau Peling dan Pulau Bakalan dengan membuat plot di empat titik kawasan ekosistem mangrove. Pembuatan preparat anatomi daun dilakukan dengan metode paraffin-tert-butanol dan sayatan paradermal. Karakter anatomi sebagai bentuk adaptasi terhadap habitat saline ditemukan di seluruh spesies tumbuhan mangrove antara lain kutikula dan epidermis yang tebal, daun yang tebal serta jaringan penyimpan air (hipodermis). Selain itu, ditemukan ciri khas daripada genus Rhizophora yaitu keberadaan cork warts dan sklereid. Hasil pengamatan karakter secara kuantitatif, rasio mesofil (palisade terhadap sponge) berkisar antara $0,28 \pm 0,04 \mu \mathrm{m}$ hingga $1,19 \pm 0,42 \mu \mathrm{m}$, rasio ketebalan daun berkisar antara 289,41 $\pm 38,21 \mu \mathrm{m}$ hingga 695,20 $\pm 97,50 \mu \mathrm{m}$, dan kerapatan stomata tertinggi dimiliki oleh Lumnitzera littorea.
\end{abstract}

Kata kunci : cork warts; hipodermis; rasio mesofil; saline

\section{PENDAHULUAN}

Mangrove merupakan ekosistem yang tumbuh pada kawasan pesisir yang berada di daerah peralihan air tawar dan air laut. Berdasarkan data Badan Informasi Geospasial (BIG) tahun 2009 disebutkan bahwa luasan mangrove di Indonesia 
mencapai $\pm 3,2$ juta hektar (Saputro, 2009) dan hal ini menunjukkan bahwa Indonesia merupakan salah satu negara dengan ekosistem mangrove yang terluas. Kekayaan spesies mangrove di Indonesia tergolong besar yaitu 40 spesies dari total 52 spesies yang termasuk dalam spesies-spesies mangrove sejati (Giesen et al., 2006).

Ekosistem mangrove mempunyai karakter yang unik dibandingkan dengan tipe ekosistem lainnya karena adanya pembentukan zonasi. Pembentukan zonasi tersebut dipengaruhi antara lain oleh geomorfologi, adaptasi terhadap salinitas, pengaruh pasang surut dan lingkungan kimia fisik (Lugo dan Snedaker, 1974; Snedaker, 1982; Giesen et al., 2006). Umumnya, zonasi yang terbentuk mempunyai komposisi dan struktur spesies yang berbeda karena terdapat proses adaptasi masing-masing spesies terhadap habitatnya.

Salah satu bentuk adaptasi yang dapat diamati adalah struktur anatomi. Struktur anatomi yang terbentuk memiliki karakter khas yang berbeda dibandingkan tumbuhan terestrial karena adaptasinya terhadap lingkungan yang saline. Spesies-spesies mangrove memiliki struktur anatomi menyerupai tumbuhan yang hidup dengan kecaman kering (bersifat xerophytic) (Lugo dan Snedaker, 1974), antara lain memiliki jaringan penyimpan air yang hadir di bagian bawah jaringan epidermis (Seshavatharam dan Srivalli, 1989), letak stomata tenggelam, kutikula dan daun tebal (Kathiresan dan Bingham, 2001). Struktur jaringan yang hadir sebagai bentuk adaptasi yang berfungsi dalam kegiatan metabolisme (i.e. fotosintesis, transpirasi dan respirasi). Beberapa penelitian yang mengkaji mengenai adaptasi tumbuhan mangrove terhadap lingkungannya antara lain kerapatan stomata terhadap salinitas (Peel et al., 2017) dan karakter anatomi tumbuhan mangrove sebagai bentuk adaptasi terhadap habitatnya (Lucena et al., 2011; Nurnida et al., 2012; Vinoth et al., 2019).

Sesuai dengan teori pembentukan zonasi ekosistem mangrove, kehadiran jenis pada setiap zonasi yang berbeda diduga memiliki karakternya tersendiri. Namun demikian, belum ada informasi mengenai adaptasi spesies pada masing-masing zonasi ekosistem mangrove. Oleh karena itu, berdasarkan hal-hal di atas, penelitian ini bertujuan untuk melihat perbedaan karakter struktur anatomi daun pada setiap spesies penyusun komunitas di masing-masing zonasi mangrove dan persamaan dan/atau perbedaan karakter masing-masing spesies penyusun mangrove sebagai bentuk adaptasinya terhadap perbedaan zonasi yang ditempatinya.

\section{MATERI DAN METODE}

Pengambilan sampel penelitian daun dilakukan di kawasan mangrove yang berada di Pulau Peling dan Pulau Bakalan pada tanggal 25 Juni hingga 12 Juli 2019. Kedua pulau tersebut merupakan dua pulau utama di wilayah Kabupaten Banggai Kepulauan.

Terdapat empat titik kawasan ekosistem mangrove untuk pengambilan sampel (Gambar 1) kawasan mangrove Desa Koyo Bunga Kecamatan Peling Tengah (Plot A); Desa Binuntuli Kecamatan Liang (Plot B); Desa Mansamat Kecamatan Tinangkung Selatan (Plot C); dan Desa Bungin Kecamatan Tinangkung (Plot D). Lokasi keempat (Plot D) terletak di Desa Bungin berada di Pulau Bakalan sedangkan ketiga plot lainnya berada di Pulau Peling. Keempat plot tersebut mempunyai komposisi spesies yang berbeda (Tabel 1).

Plot A memiliki satu zonasi mangrove yang tersusun atas Rhizophora apiculata dari depan hingga batas daratan. Plot $B$ juga memiliki satu zonasi mangrove tetapi terdapat 2 spesies penyusun yang hidup bercampur, yaitu $R$. apiculata dan Bruguiera cylindrica. Plot $C$ terdiri dari 2 zonasi mangrove dengan $R$. apiculata berada di zona depan, B. cylindrica dan Avicennia lanata di zona tengah. Pada lokasi terakhir juga terdapat 2 zona, zona depan diisi oleh $R$. apiculata, zona tengah diisi oleh Lumnitzera racemosa, L. littorea, dan Sonneratia alba. Zona tengah pada Plot $D$ ini jarang ditemui mengingat $S$. alba biasa tumbuh di zona depan dengan salinitas tinggi. Namun mengingat lokasi ini memiliki substrat pasir 
dan berada pada cekungan sehingga memungkinkan dominansi air laut masuk hingga wilayah batas daratan.

Pembuatan preparat anatomi daun dilakukan dengan metode paraffin-tertbutanol berdasarkan (Sass, 1951) yang telah dimodifikasi, sedangkan sayatan paradermal berdasarkan pada (Cutler, 1978). Parameter yang diukur adalah kerapatan dan ukuran (panjang dan lebar) stomata, lebar kutikula, lebar epidermis, lebar jaringan palisade, lebar jaringan sponge, lebar jaringan hipodermis dan tebal daun secara keseluruhan. Pengamatan menggunakan mikroskop cahaya Leitz Wetzlar dan pengambilan foto dengan mikroskop Nikon Eclipse 80i. ANOVA dan korelasi antar karakter yang dianalisis menggunakan program R versi 3.3.3 (R Core Team, 2019).

\section{HASIL DAN PEMBAHASAN}

Kabupaten Banggai Kepulauan merupakan salah satu kabupaten yang berada di antara perairan Sulawesi dan Kepulauan Sula, Maluku. Secara geografis, kepulauan ini berada di sesar aktif patahan lempeng yang menjadi bagian dari Cincin Api Pasifik. Gempa bumi dengan magnitude besar sewaktu-waktu dapat terjadi di wilayah ini. Sebagai kawasan yang berada di pesisir, mangrove menjadi kawasan esensial dalam mengantisipasi adanya bahaya gelombang tsunami. Ekosistem mangrove di kawasan Banggai Kepulauan relatif terjaga dan tidak terjadi pemanfaatan secara masif. Selain itu apabila dilihat dari struktur vegetasi penyusun, ekosistem mangrove di kawasan ini masih mengalami pertumbuhan dan perkembangan. Hal ini dicirikan dengan kepadatan individu yang rapat dan didominasi oleh tegakan dengan diameter 2$10 \mathrm{~cm}$.

Keragaman spesies mangrove di Banggai Kepulauan dipengaruhi oleh kadar garam atau salinitas perairan laut yang berada di kawasan pesisir. Salinitas akan memiliki kadar yang tinggi apabila masukan air tawar dari sungai sedikit. Namun sebaliknya, apabila terdapat sungai besar yang bermuara di wilayah estuari akan mengurangi kadar garam yang masuk ke wilayah mangrove.

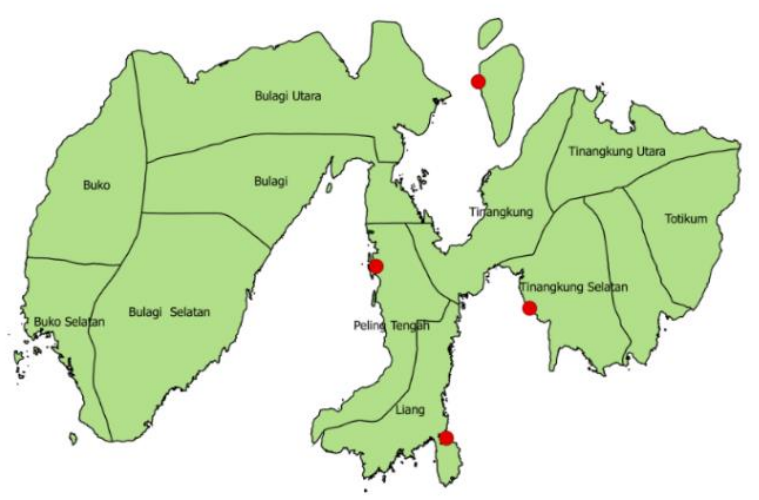

Legenda

- Lokasi Pengambilan Data

$\square$ Wilayah Kabupaten Banggai Kepulauan

- Garis Batas Kecamatan

Skala 1:500.000

Pengambilan Sampel Mangrove

Dillaksanakan pada Tanggal 25 Juni sd 12 Juli 2019

Gambar 1. Lokasi pengambilan sampel spesies Mangrove di Banggai Kepulauan (Sumber: Badan Informasi Geospasial, 2020)

Tabel 1. Spesies vegetasi penyusun hutan mangrove di lokasi penelitian

\begin{tabular}{ccc}
\hline Lokasi & Zona Depan & Zona Tengah \\
\hline Plot A & \multicolumn{2}{c}{ Rhizophora apiculata \& Bruguiera cylindrica } \\
Plot B & Rhizophora apiculata & Bruguiera cylindrica \& Avicennia lanata \\
Plot C & Lumnitzera littorea, Sonneratia alba \& \\
Plot D & Rhizophora apiculata & Lumnitzera racemosa \\
\hline
\end{tabular}


Secara umum ekosistem mangrove di lokasi penelitian dikategorikan dalam dua (2) zona, yaitu zona depan yang langsung berhadapan dengan lautan, dan zona tengah yang terletak di belakang zona terbuka. Noor et al., (2006) menyebutkan bahwa Sonneratia alba biasa dijumpai pada kawasan yang benar-benar dipengaruhi air laut. Zona tengah pada umumnya ditumbuhi oleh spesies-spesies dari genus Rhizophora dan B. cylindrica. Spesies R. mucronata dijumpai pada dominansi substrat lumpur sedangkan $R$. stylosa tumbuh pada dominansi substrat pasir. Sementara itu, $R$. apiculata menyukai kawasan dengan masukan air laut yang kuat dan masukan air tawar permanen sedangkan $L$. racemosa dan L. littorea merupakan vegetasi yang mendiami substrat pasir dengan masukan air laut dan air tawar yang seimbang.

Lingkungan ekosistem mangrove yang tergenang air laut dengan kadar garam tertentu mempengaruhi variasi anatomi tumbuhan, misalnya struktur anatomi daun yang terpengaruh secara signifikan dalam peranannya untuk proses fotosintesis (Dickinson, 1998). Umumnya, kondisi salinitas dan genangan air laut mempengaruhi kehadiran kutikula, susunan epidermis, jaringan hipodermis dan rasio jaringan mesofil (Vinoth et al., 2019) terhadap ketebalan daun serta kehadiran kelenjar garam pada daun.

\section{Kutikula dan epidermis}

Kutikula ditemukan di seluruh spesies dengan ketebalan berbeda-beda (Tabel 3). Anggota genus Lumnitzera memiliki kutikula sangat tipis, sedangkan kutikula paling tebal dimiliki oleh B. cylindrica dengan ketebalan mencapai 7,05 um (Gambar 2). Seluruh spesies memiliki selapis epidermis di bagian atas dan bawah daun dengan ketebalan yang bervariasi antar spesies. Namun demikian, pada umumnya epidermis atas lebih tebal dibandingkan epidermis bawah. Kutikula dan epidermis yang tebal merupakan satu bentuk adaptasi tumbuhan untuk mengurangi laju transpirasi. Keduanya dapat menjadi penghalang (barrier) hilangnya air secara berlebihan dari tubuh tumbuhan (Hill dan Popp, 1950; Nandy et al., 2005). Ciri ini serupa dengan tumbuhan xeromorfic yang diakibatkan oleh adanya intensitas penyinaran yang tinggi disertai kandungan air yang minim akibat kondisi saline pada ekosistem mangrove.

\section{Tipe, ukuran dan kerapatan stomata}

Seluruh spesies berdaun hypostomatic (stomata berada di permukaan bawah daun), kecuali L. littorea, L. racemosa dan S. alba yang bertipe amphistomatic (stomata berada di kedua permukaan daun). Tipe stomata pada umumnya bertipe anomositik, anisositik, siklositik, tetapi terkadang dijumpai stomata bertipe staurositik. Stomata terletak tenggelam terhadap epidermis (sunken). Hanya stomata pada A. lanata yang sulit diamati karena lapisan sel epidermis tertutup oleh trikoma glandular yang sangat rapat (Gambar 3).

Ukuran panjang dan lebar stomata antar spesies di seluruh plot penelitian beragam (Tabel 2). Kerapatan stomata tertinggi pada kedua spesies Lumnitzera, kemudian diikuti oleh $B$. cylindrica dan $R$. apiculata (Tabel 2). Khusus untuk R. apiculata yang ditemukan di seluruh plot penelitian, panjang stomata berbeda secara signifikan antara R. apiculata pada plot $A$ dengan spesies yang sama di plot lain (plot B, C, D), sedangkan lebar stomata yang berbeda nyata hanya antara $R$. apiculata pada plot $A$ dengan $R$. apiculata pada plot D. Kerapatan stomata antar $R$. apiculata di empat lokasi berbeda nyata seluruhnya kecuali pada $R$. apiculata plot A dengan R.apiculata plot D. Kehadiran trikoma hanya teramati pada $A$. lanata dengan tipe multiselular glandular (Gambar 3C). Trikoma tersebar di permukaan bawah daun dan tersusun sangat rapat. Hasil penelitian ini sesuai dengan hasil penelitian (Vinoth et al., 2019) yang menyatakan bahwa kutikula pada kelompok Avicennia berselang-seling dengan trikoma nonglandular dan glandular.

\section{Hipodermis}

Jaringan penyimpan air pada spesies mangrove berupa jaringan sub-epidermis (hipodermis) yang terletak di bawah lapisan epidermis (Gambar 4). Setiap spesies memiliki ketebalan lapisan hipodermis yang berbeda (Tabel 3). R. apiculata mempunyai hipodermis paling tebal dibandingkan dengan spesies lainnya, sedangkan kedua 


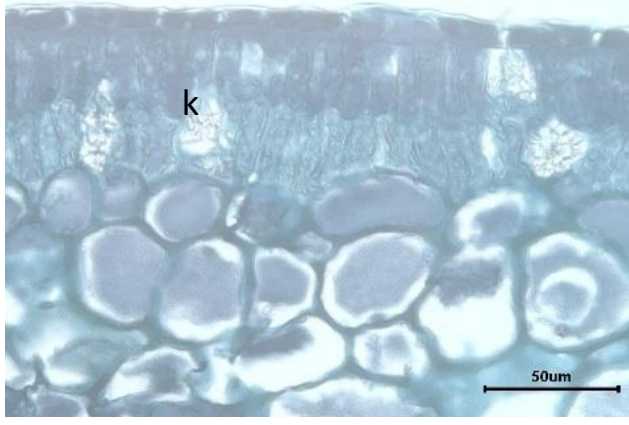

(a)

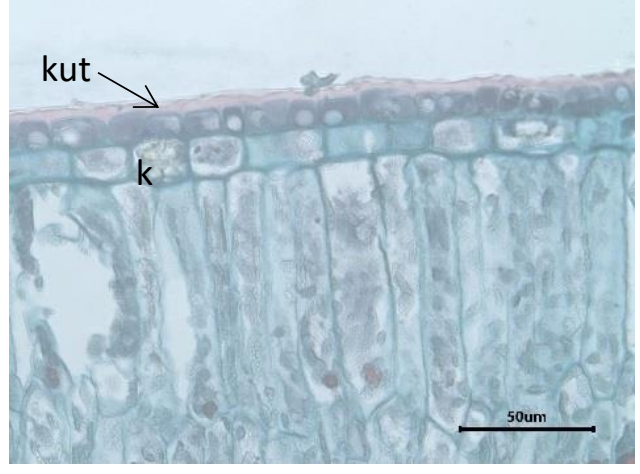

(b)

Gambar 2. Kehadiran kutikula: (A) sangat tipis pada L. littorea dan (B) tebal pada B. cylindrica (kut: kutikula, k: kristal druse)

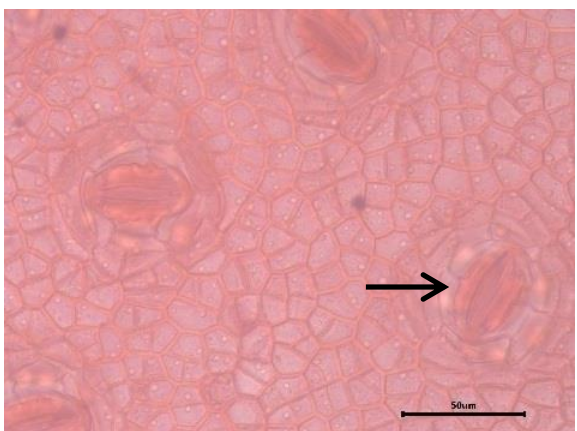

(a)

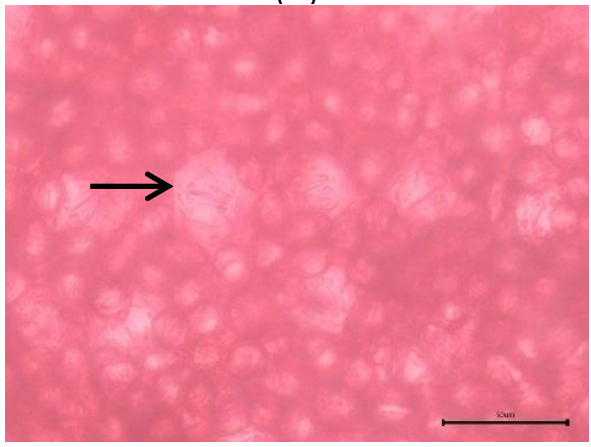

(c)

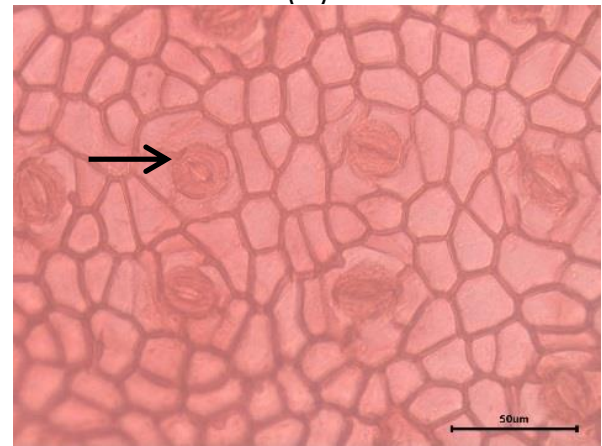

(e)

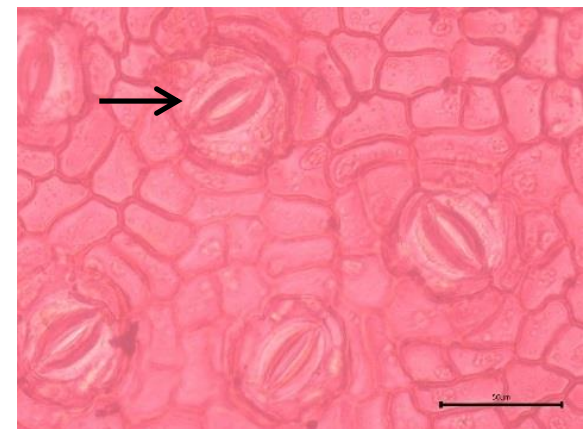

(b)

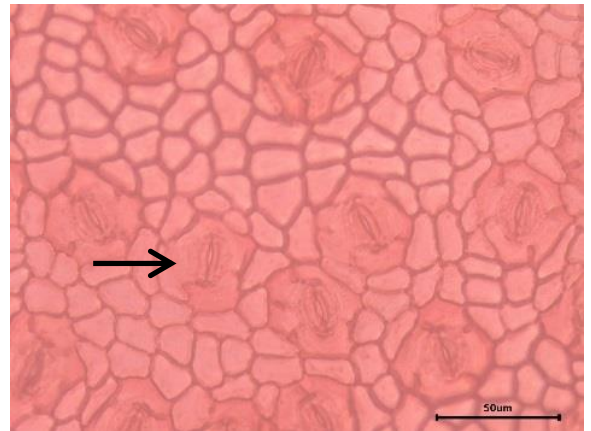

(d)

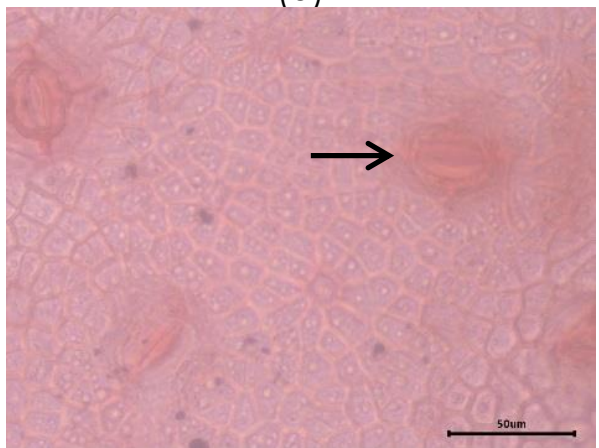

(f)

Gambar 3. Tipe stomata: (A) anomositik pada R. apiculata, (B) staurositik dan anomositik pada B. cylindrica, (C) tidak jelas pada A. lanata, (D) anisositik dan anomositik pada L. littorea, (E) anisositik dan anomositik pada L. racemosa, dan (F) staurositik dan anomositik pada S. alba. Stomata ditunjukkan oleh tanda panah. 
spesies Lumnitzera dan S. alba tidak memiliki hipodermis. Kedua spesies Lumnitzera memiliki jaringan penyimpan air (water storage) di bagian tengah daun berupa jaringan berdinding sel tipis tanpa klorofil.

Hipodermis pada tumbuhan mangrove merupakan jaringan penting untuk penyimpanan air sebagai bentuk adaptasi terhadap lingkungan yang saline. Rasio hipodermis terhadap tebal daun yang berbeda-beda berkaitan dengan adaptasi masing-masing spesies. Rasio hipodermis terhadap tebal daun pada $R$. apiculata yang lebih tinggi dibandingkan dengan spesies lain (Gambar 5) mengindikasikan bahwa $R$. apiculata mempunyai kapasitas penyimpanan air lebih besar dibandingkan dengan spesies lainnya untuk mencegah terjadinya kekeringan. Selain itu, keberadaannya pada zona depan yang terkena air laut menunjukan bahwa spesies ini

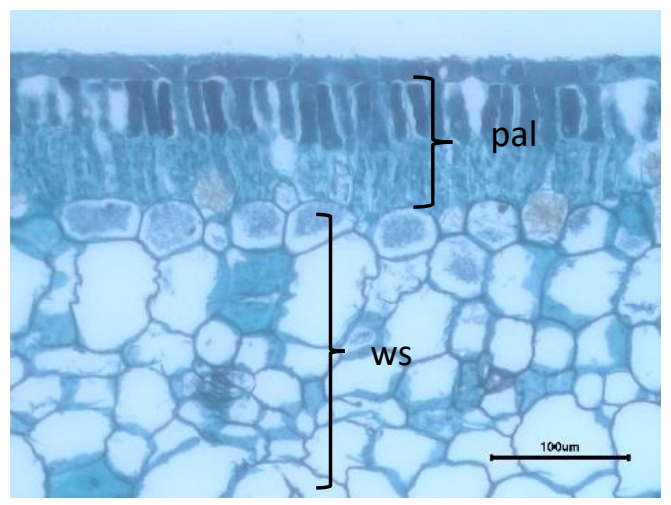

(a)

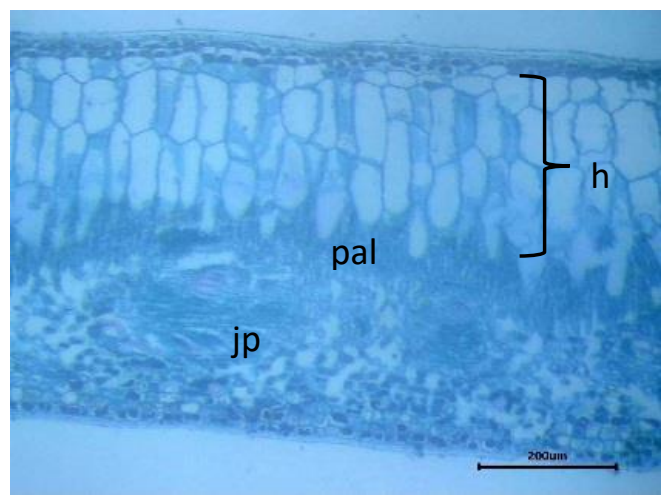

(c) cukup tahan terhadap cekaman salinitas yang tinggi.

\section{Mesofil}

Seluruh spesies pada penelitian ini mempunyai jaringan mesofil yang terdiri dari jaringan palisade dan sponge. Jaringan palisade dan sponge tersusun dari beberapa lapisan. Namun demikian, pada dua spesies dari genus Lumnitzera dan Sonneratia, mempunyai palisade di kedua sisi daun yaitu atas dan bawah. Struktur tersebut merupakan bentuk adaptasi ekofisiologi pada ketiga spesies tersebut yang didukung oleh kerapatan stomata yang tinggi. Hal ini dimungkinkan karena adanya persaingan untuk mendapatkan cahaya, serta penyesuaian spesies terhadap penyinaran yang intens. Menurut Bacelar et al. (2004); Nandy et al., (2005), keberadaan stomata dan jaringan mesofil turut berperan dalam keberlangsungan spesies-spesies mangrove.

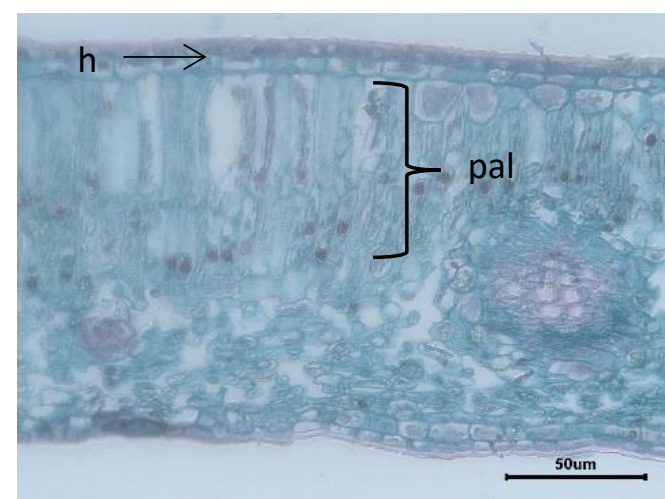

(b)

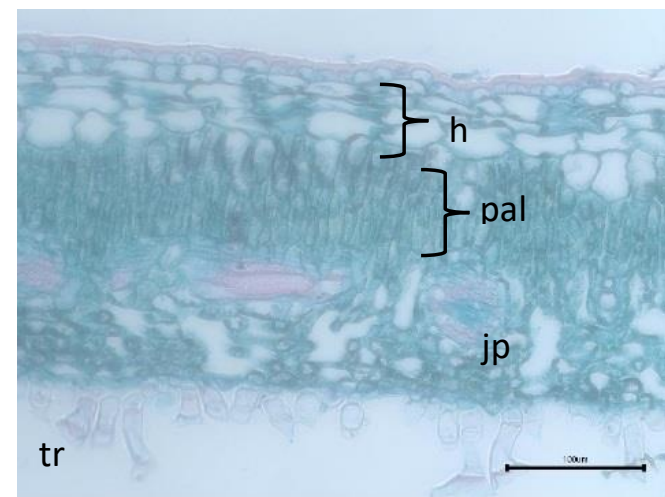

(d)

Gambar 4. Jaringan penyimpan air : (A) L. racemosa tanpa hipodermis, (B) B. cylindrica dengan selapis hipodermis, (C) R. apiculata dan (D) A. lanata dengan lebih dari selapis hipodermis (h: hipodermis, jp: jaringan pengangkut, pal: palisade, tr: trikoma, ws: water storage) 


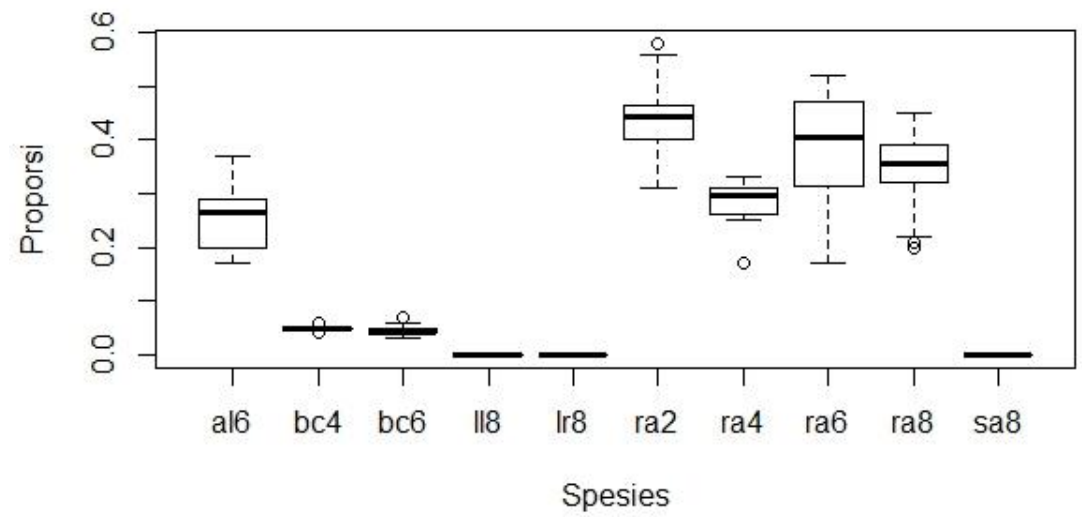

Gambar 5. Rasio hipodermis terhadap tebal daun (al6: A. lanata; bc4, bc6: B. cylindrica, II8: L. littorea; Ir8: L. racemosa; ra2, ra4, ra6, ra8: R. apiculata; sa8: S. alba).

Rasio palisade terhadap sponge berkisar antara $0.28 \pm 0,04 \mu \mathrm{m}$ hingga $1,19 \pm$ $0,42 \mu \mathrm{m}$ (Gambar 6), dengan rasio paling tebal dimiliki oleh B. cylindrica dan A. lanata yang mencapai masing-masing $1,08 \pm 0,53$ $\mu \mathrm{m}$ dan $1,19 \pm 0.42 \mu \mathrm{m}$. Karakter tersebut menunjukkan bahwa palisade menjadi jaringan penting dalam proses fotosintesis. Rasio palisade terhadap sponge yang tinggi memperlihatkan keefektifan jaringan tersebut dalam proses fotosintesis untuk mendapatkan dan penyebaran cahaya serta menangkap $\mathrm{CO}_{2}$. Berdasarkan Chartzoulakis et al. (2000), peningkatan mesofil merupakan salah satu faktor penting pengikat $\mathrm{CO}_{2}$ dalam fotosintesis terutama dalam kondisi stres air (kekeringan).

Hasil penelitian mendapatkan hubungan antara kerapatan stomata dan rasio jaringan mesofil berupa peningkatan kerapatan stomata seiring dengan menurunnya rasio jaringan mesofil (Gambar 7). Hal ini berbeda dengan Nandy et al. (2005) yang menyatakan bahwa terdapat korelasi positif antara kerapatan stomata dan mesofil terhadap proses fotosintesis, namun berbanding terbalik dengan ukuran stomata.

Peningkatan tinggi rasio mesofil memperlihatkan semakin lebar jaringan palisade semakin meningkatkan efektifitas fotosintesis (Chartzoulakis et al., 2000). Adapun tinggi rendahnya kerapatan stomata berhubungan dengan proses transpirasi tumbuhan mangrove dalam rangka untuk menyeimbangkan kandungan air pada tubuh tumbuhan (Peel et al., 2017).

\section{Kehadiran R. apiculata di seluruh plot}

Seluruh variabel yang diukur berbeda secara signifikan, kecuali tebal kutikula bawah dan hipodermis, menunjukkan bahwa di keempat plot tersebut mempunyai kondisi lingkungan yang tidak sama sehingga mempengaruhi struktur jaringan daun spesies tersebut. Keberadaan R. apiculata di seluruh plot menandakan bahwa R. apiculata mempunyai kemampuan bertahan hidup lebih baik dari spesies lainnya (Sereneski-De Lima et al., 2013). Hal tersebut karena genus Rhizophora merupakan tumbuhan pionir yang tergolong sebagai tumbuhan penyusun awal dalam suksesi (Snedaker, 1982; Sukardjo, 1984). Pada plot $A$, hanya ditemukan $R$. apiculata menunjukkan bahwa hutan mangrove pada kawasan ini masih dalam tahap pembentukan hutan mangrove muda sehingga hanya terdapat satu lapis tajuk. Sementara itu plot lainnya merupakan hutan mangrove campuran, yang terdiri dari beberapa spesies sebagai penanda hutan mangrove muda sedang mengalami perkembangan selanjutnya (Sukardjo, 1984).

Karakter khas terlihat pada R. apiculata adalah kehadiran cork warts dan sklereid (Gambar 8). Cork warts merupakan jaringan yang tersusun dari suberin, berada di bagian bawah epidermis yang berfungsi dalam pertukaran udara (Joffily dan Vieira, 2010). Selain sebagai karakter khusus bagi genus Rhizophora, merupakan jalan masuk udara, kemudian udara akan disimpan ke aerenkima daun. Selain itu, mengoptimalkan proses fotosintesis (Lucena et al., 2011). 
Tabel 2. Karakter mikromorfologi enam spesies tumbuhan mangrove di seluruh lokasi penelitian

\begin{tabular}{|c|c|c|c|c|c|c|}
\hline \multirow[b]{2}{*}{ Plot } & \multirow[b]{2}{*}{ Spesies } & \multicolumn{2}{|c|}{ Stomata atas } & \multicolumn{2}{|c|}{ Stomata bawah } & \multirow{2}{*}{$\begin{array}{c}\text { Kerapatan } \\
\text { stomata } \\
\text { bawah } \\
\text { (jumlah/mm²) }\end{array}$} \\
\hline & & Panjang ( $\mu \mathrm{m})$ & $\begin{array}{c}\text { Lebar } \\
(\mu \mathrm{m})\end{array}$ & Panjang ( $\mu \mathrm{m})$ & $\begin{array}{c}\text { Lebar } \\
(\mu \mathrm{m})\end{array}$ & \\
\hline A & R. apiculata & - & - & $41.98 \pm 2.28$ & $29.19 \pm 1.81$ & $82.91 \pm 13.37$ \\
\hline \multirow[t]{2}{*}{$B$} & R. apiculata & - & - & $46.90 \pm 1.58$ & $30.83 \pm 3.17$ & $50.60 \pm 1.63$ \\
\hline & B. cylindrica & - & - & $27.06 \pm 1.80$ & $21.65 \pm 2.89$ & $107.63 \pm 28.90$ \\
\hline \multirow[t]{3}{*}{ C } & R. apiculata & - & - & $45.26 \pm 2.52$ & $30.50 \pm 2.40$ & $70.07 \pm 5.96$ \\
\hline & B. cylindrica & - & - & $39.36 \pm 6.03$ & $28.62 \pm 5.15$ & $89.02 \pm 11.36$ \\
\hline & A. lanata & - & - & $25.47 \pm 2.68$ & $19.68 \pm 1.49$ & $23.46 \pm 11.08$ \\
\hline \multirow[t]{4}{*}{$D$} & R. apiculata & - & - & $46.25 \pm 3.03$ & $32.03 \pm 2.54$ & $78.51 \pm 4.99$ \\
\hline & L. littorea & $26.57 \pm 1.81$ & $19.35 \pm 1.47$ & $26.73 \pm 1.93$ & $20.34 \pm 2.28$ & $173.78 \pm 13.08$ \\
\hline & L. racemosa & $29.85 \pm 2.63$ & $24.49 \pm 2.06$ & $30.18 \pm 2.18$ & $24.05 \pm 2.33$ & $129.97 \pm 5.69$ \\
\hline & S. alba & $41 \pm 3.08$ & $29.30 \pm 2.57$ & $40.02 \pm 3.15$ & $29.74 \pm 2.98$ & $66.99 \pm 5.36$ \\
\hline
\end{tabular}

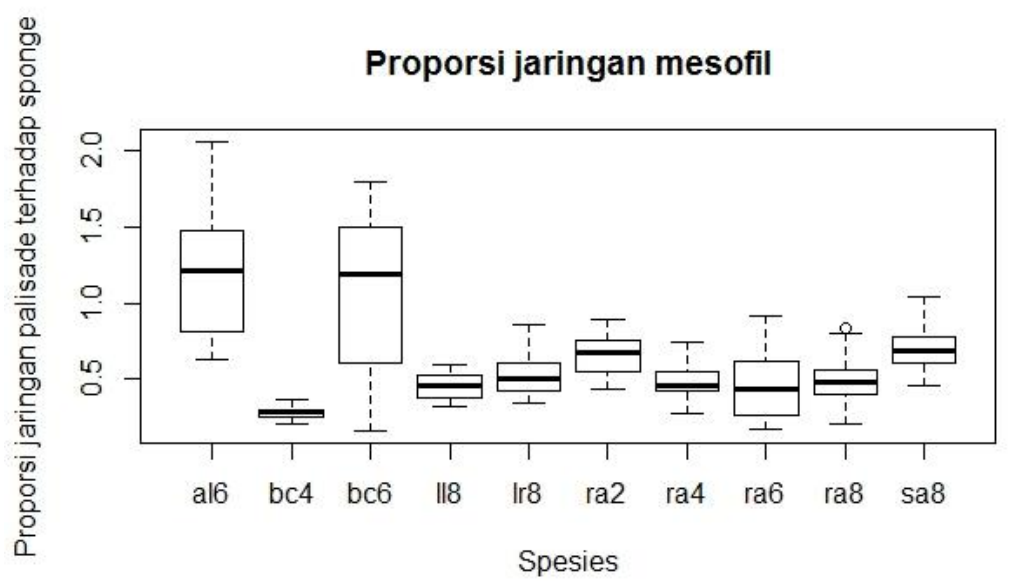

Gambar 6. Rasio jaringan mesofil daun pada enam spesies mangrove (al6: A. lanata; bc4, bc6: B. cylindrica, II8: L. littorea; Ir8: L. racemosa; ra2, ra4, ra6, ra8: R. apiculata; sa8: S. alba)

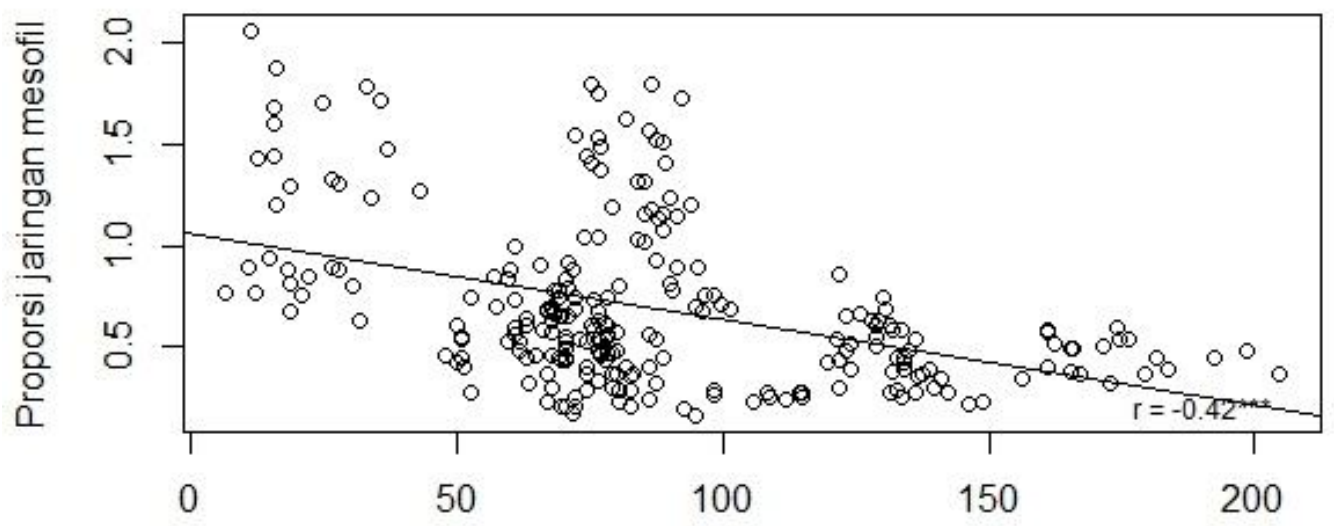

Kerapatan stomata

Gambar 7. Korelasi kerapatan stomata dan jaringan mesofil spesies pembentuk zonasi mangrove 


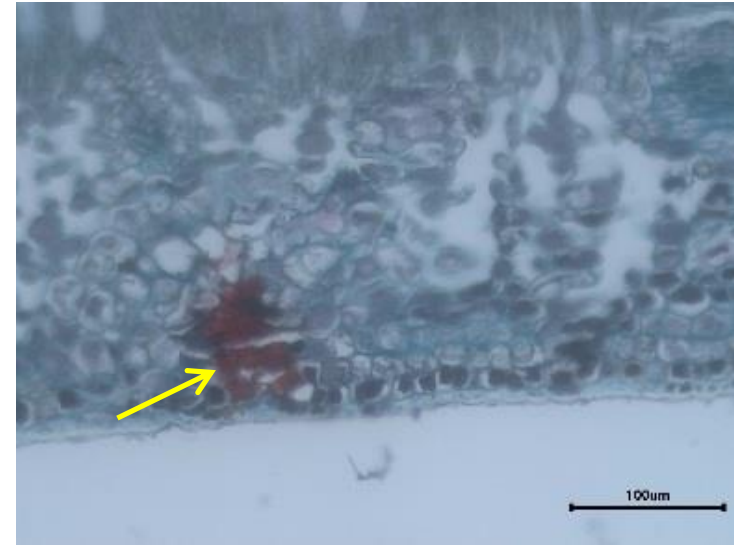

(a)

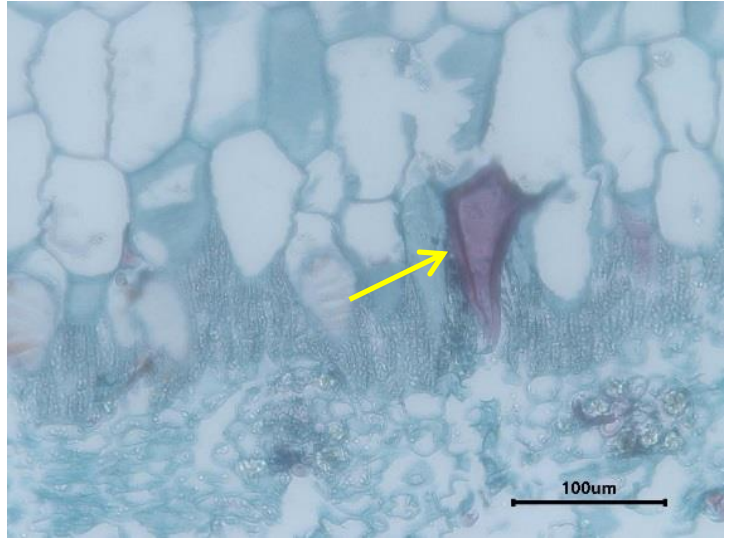

(b)

Gambar 8. Karakter pada R. apiculata: a) Cork warts dan b) Sklereid di organ daun

Tabel 3. Nilai kuantitatif karakter mikromorfologi enam spesies mangrove

\begin{tabular}{|c|c|c|c|c|c|c|c|c|c|c|}
\hline \multirow{2}{*}{ Plot } & \multirow{2}{*}{ Jenis } & \multicolumn{2}{|c|}{ Kutikula $(\mu \mathrm{m})$} & \multicolumn{2}{|c|}{ Epidermis ( $\mu \mathrm{m})$} & \multirow{2}{*}{ Hipodermis $(\mu \mathrm{m})$} & \multicolumn{2}{|c|}{ Palisade $(\mu \mathrm{m})$} & \multirow{2}{*}{$\begin{array}{c}\text { Sponge } \\
(\mu \mathrm{m})\end{array}$} & \multirow{2}{*}{$\begin{array}{l}\text { Tebal daun } \\
(\mu \mathrm{m})\end{array}$} \\
\hline & & atas & bawah & atas & bawah & & atas & bawah & & \\
\hline A (2 Juli) & R. apiculata & $4.43 \pm 1.61$ & $3.28 \pm 0$ & $11.48 \pm 1.68$ & $10.00 \pm 1.29$ & $311.11 \pm 82.19$ & $141.04 \pm 19.07$ & 0 & $221.56 \pm 42.19$ & $695.20 \pm 97.50$ \\
\hline \multirow[t]{2}{*}{ B (4 Juli) } & R. apiculata & $3.28 \pm 0$ & $3.28 \pm 0$ & $11.81 \pm 1.70$ & $9.84 \pm 1.55$ & $148.58 \pm 27.18$ & $114.14 \pm 16.64$ & 0 & $242.06 \pm 44.14$ & $526.44 \pm 43$ \\
\hline & B. cylindrica & $7.05 \pm 1.20$ & $3.28 \pm 0$ & $19.84 \pm 2.25$ & $12.14 \pm 1.54$ & $23.29 \pm 2.99$ & $88.40 \pm 7.18$ & 0 & $322.42 \pm 42.23$ & $466.09 \pm 45$ \\
\hline \multirow[t]{3}{*}{ C (6 Juli) } & R. apiculata & $3.61 \pm 1.01$ & $3.28 \pm 0$ & $12.30 \pm 2.09$ & $10.00 \pm 1.67$ & $231.08 \pm 94.38$ & $93.97 \pm 36.68$ & 0 & $219.10 \pm 52.12$ & $566.46 \pm 132.70$ \\
\hline & B. cylindrica & $5.33 \pm 2.31$ & $4.43 \pm 1.58$ & $14.84 \pm 2.57$ & $12.30 \pm 3.04$ & $17.96 \pm 2.78$ & $168.51 \pm 53.79$ & 0 & $205.66 \pm 111 . .48$ & $419.27 \pm 80.30$ \\
\hline & A. lanata & $3.94 \pm 1.33$ & 0 & $9.95 \pm 1.05$ & $7.11 \pm 1.51$ & $75 \pm 21.60$ & $103.65 \pm 19.93$ & 0 & $93.70 \pm 22.49$ & $289.41 \pm 38.21$ \\
\hline \multirow[t]{4}{*}{ D (8 Juli) } & R. apiculata & $3.72 \pm 1.13$ & $3.50 \pm 0.83$ & $12.57 \pm 2.29$ & $11.37 \pm 2.69$ & $169.58 \pm 40.09$ & $93.04 \pm 18.16$ & 0 & $194.94 \pm 30.84$ & $481.50 \pm 52.11$ \\
\hline & L. littorea & 0 & 0 & $12.79 \pm 1.47$ & $10.66 \pm 1.80$ & 0 & $88.56 \pm 7.45$ & $54.94 \pm 12.08$ & $321.11 \pm 40.94$ & $488.06 \pm 39.25$ \\
\hline & L. racemosa & 0 & 0 & $15.31 \pm 2.63$ & $16.07 \pm 2.63$ & 0 & $97.09 \pm 10.95$ & $77.52 \pm 13.63$ & $350.96 \pm 71.06$ & $556.94 \pm 76.55$ \\
\hline & S. alba & $3.28 \pm 0$ & 0 & $21.65 \pm 3.40$ & $18.04 \pm 2.40$ & 0 & $117.42 \pm 14.70$ & $84.84 \pm 13.91$ & $295.31 \pm 59.72$ & $537.26 \pm 70.78$ \\
\hline
\end{tabular}

\section{KESIMPULAN}

Karakter anatomi pada spesies mangrove memiliki ciri menyerupai tumbuhan xerofit yaitu berdaun tebal, memiliki hipodermis dan berkutikula tebal. Spesies yang berhadapan langsung dengan air laut memiliki kutikula yang tebal dan jaringan hipodermis berlapis-lapis, yaitu $R$. apiculata dan B. cylindrica (zona depan). Kedua spesies Lumnitzera dan S. alba (zona tengah) beradaptasi dengan lingkungan saline dangan jaringan mesofil yang tebal dan kerapatan stomata yang cukup tinggi.

\section{DAFTAR PUSTAKA}

Bacelar, E. A., Correia, C.M., MoutinhoPereira, J.M., Goncalves, B. C., Lopes, J. I. \& Torres-Pereira, J.M.G. 2004. Sclerophylly and leaf anatomical traits of five field- grown olive cultivars growing under drought conditions, Tree Physiolog., 24(2):233-239. doi: 10.1093/treephys/ 24.2.233.

Badan Informasi Geospasial. 2020. Indonesia Geospatial Portal. http://tanahair. indonesia.go.id/portal-web/download/ perwilayah [diakses 27 Januari 2020].

Chartzoulakis, K., Bosabalidis, A., Patakas, A., \& Vemmos, S. 2000. Effects of water stress on water relations, gas exchange and leaf structure of olive tree Acta Hortic., 537:241-247. doi: 10.17660/ActaHortic. 2000.537.25.

Cutler, D. 1978. Applied Plant Anatomy. Longman, London \& New York. 103 hal

Dickinson, W.C. 1998. Integrative Plant Anatomy. San Diego, San Francisco, New York, Boston, London, Toronto, Sydney, Tokyo: Harcourt Academic Press. 533 hal 
Giesen, W. Wulffraat, S., Zieren, M. \& Scholten, L. 2006. Mangrove Guidebook of South East Asia. Bangkok: FAO and Wetlands International. $198 \mathrm{hal}$

Hill, B.J. \& Popp, H. W. 1950. Botany: A text book for colleges. New York, Toronto \& London: McGraw-Hill Book Company, Inc. 710 hal

Joffily, A. \& Vieira, C.R. 2010. Cork-warts on the leaf epidermis of four genera of Celastroidea-Celastraceae, $\quad$ Flora: Morphology, Distribution, Functional Ecology of Plants. 205(5):313-318. doi: 10.1016/j.flora.2009.12.014.

Kathiresan, K. \& Bingham, B.L. 2001. Biology of mangroves and mangrove ecosystems. Adv. Mar. Biol., 40: 84-254. doi: 10.1016/ S0065-2881 (01)40003-4.

Lucena, I. Maciel, V.E.O., Silva, J.B.da., Galvincio, J.D., \& Pimentel, R.M.de M. 2011. Leaf Structure of Mangrove Species To Understand the Spectral Responses. J. Hyperspec. Rem. Sens., 1(2):19-31. doi: 10.5935/2237-2202.20110002.

Lugo, A.E. \&Snedaker, S.C. 1974. 'The Ecology of Mangroves', Ann. Rev. Ecolog. Systemat., 5(1):39-64. doi: 10.1146/annu rev.es.05.110174.000351.

Nandy, P., Das, S. \& Ghose, M. 2005. Relation of leaf micromorphology with photosynthesis and water efflux in some Indian mangroves. Acta Bot. Croatica, 64(2):331-340.

Noor, Y.R., Khazali, M. \& Suryadiputra I.N.N, 1999. Panduan pengenalan mangrove di Indonesia. Wetlands International Indonesia Programs. 220 hal

Nurnida, M., Talip, N. \& Ruzi, A. 2012. Nilai taksonomi ciri anatomi lamina daun dan adaptasi kepada persekitaran spesies hutan paya bakau (Rhizophoraceae), J. Trop. Mar. Ecosys., 2(2):37-44.
Peel, J.R., Mandujano Sanchez, M.C., Lopez Portillo, J. \& Golubov, J. 2017. Stomatal density, leaf area and plant size variation of Rhizophora mangle (Malpighiales: Rhizophoraceae) along a salinity gradient in the Mexican Caribbean, Rev. Biol. Trop., 65(2):701-712. doi: 10.15517/ rbt.v65i2.24372.

$\mathrm{R}$ Core, T. 2019. R: A language and environment for statistical computing., $R$ Foundation for Statistical Computing. Available at: https://www.r-project.org.

Saputro, G.B. 2009. Peta Mangrove Indonesia. Pusat Survei Sumber Daya Laut, Badan Koordinasi Survei dan Pemetaan Nasional. 329 hal

Sass, J.E. 1951. Botanical microtechnique. 2nd edition. The lowa State College Press. 219 hal

Sereneski-De Lima, C., Torres-Boeger, M. R., Larcher-de Carvalho, L., Pelozzo, A. \& Soffiatti, P. 2013. Sclerophylly in mangrove tree species from South Brazil, Rev. Mex. Biodivers. 84(4):1159-1166. doi: 10.7550/ rmb.32149.

Seshavatharam, V. \& Srivalli, M. 1989. Systematic leaf anatomy of some Indian mangroves, Proceedings: Plant Sciences, 99(6):557-565. doi: 10.1007/BF03053425.

Snedaker, S.C. 1982. Mangrove species zonation: why? In Contributions to the Ecology of Halophytes doi: 10.1007/97894-009-8037-2_8.

Sukardjo, S. 1984. Ekosistem Mangrove. Oseana, 9(4):102-115.

Vinoth, R., Kumaravel, S. \& Ranganathan, R. 2019. Anatomical and physiological adaptation of mangrove wetlands in east coast of Tamil Nadu. World Sci. News, 129: 161-179. 